Dhiru A. Thadani

\title{
Form not Content Dictates the "Smart" City
}

\section{La forma y no el contenido dicta la ciudad "inteligente"}

\author{
A forma, e não o conteúdo, determina a \\ cidade "inteligente"
}

\begin{abstract}
Resumen | Resumo
Over the past 50 years, decision-makers, laypersons, scientific communities, and design professions have repeatedly warned of the impending climate crisis caused by overdependence on fossil fuels. The environmental prophets have admonished that mother earth is on the brink of catastrophe. In response, scientific wizards have boasted that technocratic solutions will save the day. The evidence clearly indicates that a drastic change in policies, lifestyle, and consumption habits is necessary if there is to be a livable world for future generations. Urbanism is the most efficient form of habitation. Embracing and legislating for the traditional pattern of urbanism which is supported by Wi-Fi technology is the livable and sustainable prescription to address climate change and the global dependence on fossil fuels.
\end{abstract}

En los últimos 50 años, los responsables de tomar decisiones, los legos, las comunidades científicas y los profesionales del urbanismo han avisado reiteradamente sobre la inminente crisis climática provocada por la excesiva dependencia de los combustibles fósiles. Los profetas del medio ambiente han advertido de que la madre tierra está al borde de la catástrofe. Como respuesta, los genios de la ciencia proclamaron que las soluciones tecnocráticas nos sacarían del apuro. Las pruebas indican claramente que se necesita un cambio drástico en las políticas, el estilo de vida y los hábitos de consumo si queremos dejar un mundo habitable a las generaciones futuras. El urbanismo es la forma de habitar más eficiente. Adoptar y legislar para el modelo de urbanismo tradicional que se apoya en la tecnología wifi es la receta de habitabilidad y sostenibilidad para solucionar el cambio climático y la dependencia global de los combustibles fósiles.

Nos últimos 50 anos, responsáveis pela tomada de decisões, leigos, comunidades científicas e profissões de design têm alertado repetidamente para a iminente crise climática causada pela dependência excessiva dos combustíveis fósseis. Os profetas ambientais têm advertido que a mãe terra está à beira da catástrofe. Em resposta, os feiticeiros científicos gabaram-se que as soluções tecnocráticas iriam salvar o dia. As evidências indicam claramente que é necessária uma mudança drástica nas políticas, estilo de vida e hábitos de consumo para que haja um mundo habitável para as gerações futuras. O urbanismo é a forma mais eficiente de habitação. Adoptar e legislar para um modelo tradicional de urbanismo que é apoiado pela tecnologia Wi-Fi é a receita habitável e sustentável para enfrentar as alterações climáticas e a dependência global dos combustíveis fósseis. 


\section{Lament}

Those who learn from history are forced to live with those who do not.

We suffer the consequences of the ignorant repeating known mistakes.

\section{Unspoken Truths}

1. Form has always been the primary interest of the architectural designer.

2. Within the design professions, peer recognition is valued higher than the opinions, needs, and desires of the end-users.

3. In the moment of euphoric passion while making what the designer believes is an original form, common sense is dismissed and hubris takes over.

These unspoken truths can be expressed by the formula: Hubris + Form - Common Sense $=$ Notoriety $=$ Stardom

\section{FORM NOT CONTENT DICTATES THE 'SMART' CITY}

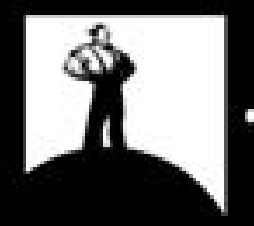

HLPRS

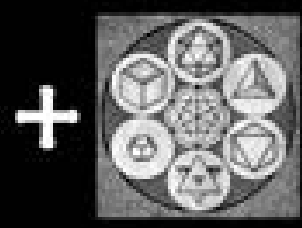

FORM

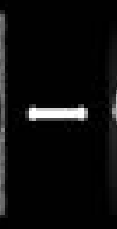

COMMONSENSE

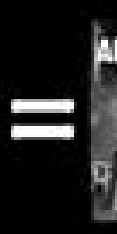

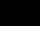

Over the past fifty years, three revelations have warned decision-makers, laypersons, the scientific community, and the design professions of the impending climate crisis caused by overdependence on fossil fuels. The environmental prophets have admonished that mother earth is on the brink of catastrophe. In response, scientific wizards have boasted that technocratic solutions will save the day. The evidence clearly indicates that a drastic change in policies, lifestyle, and consumption habits is necessary if there is to be a livable world for future generations. Despite the overwhelming evidence, the last fifty years have disclosed that the majority of Homo sapiens are unwilling to forgo the comforts that fossil-fueled technology has afforded them. And the design professions have continued to be obsessed with form in lieu of content.

\section{Revelation 1.0}

Ours is a nation of affluence. But the technology that has permitted our affluence spews out vast quantities of wastes and spent products that pollute the air, poison our waters, and even impair our ability to feed ourselves. At the same time, we have crowded together into dense metropolitan areas where concentration of wastes intensifies the problem.

Pollution now is one of the most pervasive problems of our society. With our numbers increasing, and with our increasing urbanization and industrialization, the flow of pollutants to our air, soils and waters is increasing. This increase is so rapid that our present efforts in managing pollution are barely enough to stay even, surely not enough to make the improvements that are needed. 


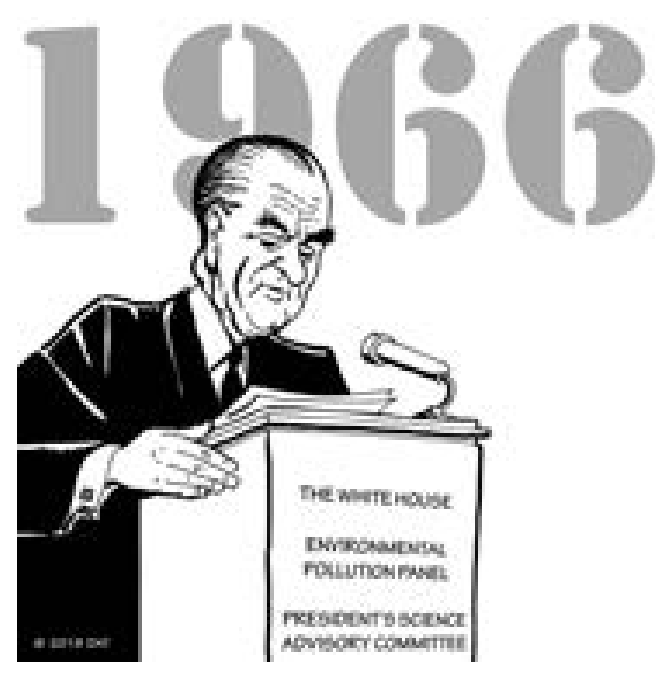

It is surprising to learn that these words were written fifty-five years ago by President Johnson in the introduction to The Report of The Environmental Pollution Panel prepared by the President's Science Advisory Committee. By all accounts, this was the first official report to any government anywhere in the world on the possible challenges arising from increased Carbon Dioxide $\left(\mathrm{CO}_{2}\right)$ levels in the atmosphere.

In the report the committee tackled a range of environmental and pollution problems in the 300page document, which outlines issues such as:

1. Soil contamination from industrial wastes, mining, and airborne contaminants.

2. Health effects of environmental pollution on humans and other living organisms.

3. Increased atmospheric carbon dioxide and effects on climate.

4. Pollutants and air quality.

5. Solid waste, salvaging, landfill, and reclamation.

6. Separation of sewage systems and storm runoff.

7. Effects of chlorinated wastes.

8. Agricultural wastes.

9. Water quality and aquatic blooms.

10. Food security and unsafe pesticides practices.

In hindsight, the 1965 report would have made Nostradamus proud, with statements such as "The climate changes that may be produced by the increased $\mathrm{CO}_{2}$ content could be deleterious from the point of view of human beings". However, these were not the words of a $16^{\text {th }}$ century oracle making a prophetic prediction, but a reputable group of scientists. The appendix of the report makes reference to three dozen scientific papers from the 1950 s and early 60 s, and even back to the $19^{\text {th }}$ century. They cover the earliest research developing the scientific understanding of how $\mathrm{CO}_{2}$ influences climate.

Sadly, the report's findings were generally ignored and no action was taken.

\section{Revelation 2.0}

The second critical warning to consider a sustainable fossil-free future occurred in October 1973. The image of lengthy lines at gas stations remains a memorable feature of that crisis. The twelve members of the Organization of the Petroleum Exporting Countries (OPEC) colluded to stop exporting oil to the United States. The embargo was retaliation toward the United States and other nation's that provided military aid to Israel in the Yom Kippur War, and their continued support during post-war negotiations. Canada, Western Europe, Japan, Australia, and New Zealand, all faced substantial petroleum shortages, real and perceived, and rising oil prices. In the US, prices escalated, exceeding a dollar a gallon in that decade.
US President Johnson announces the findings of The President's Science Advisory Committee 
During the oil embargo gas lines and acute shortages were a common occurrence in America
Scientists at major oil companies warn executives that burning of fossil fuel is warming the planet

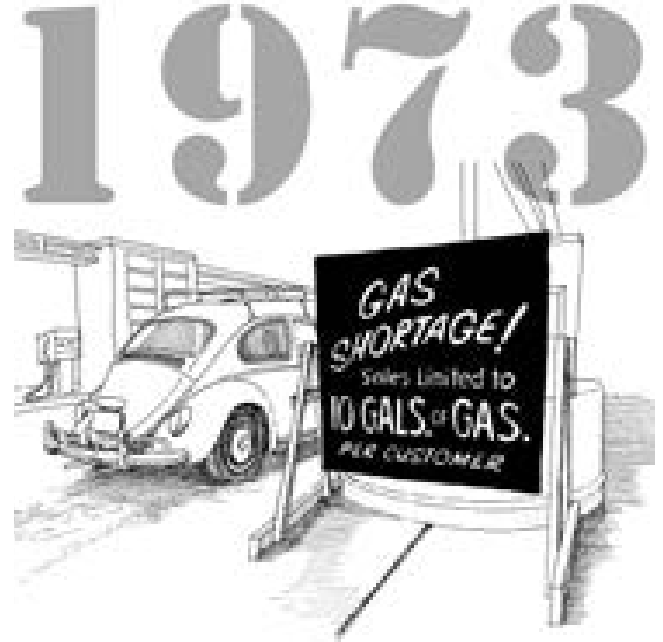

The energy turmoil experienced during the embargo helped set the US on a slow course of rising energy efficiency. Transportation, household appliances, building construction, and electric generation were industries that modified their inefficient practices. It was understood that the less energy-intensive the economy, the more resilient the country would be in dealing with future shortages. New policies were enacted, including reduction of highway travel speed to $55 \mathrm{mph}$ in an effort to improve vehicular fuel efficiency, and gas-guzzling luxury cars were taxed. The public awareness brought about the ostracizing of owners of monstrous inefficient vehicles. An unintended consequence of the oil price escalation was the resurrection of the coal industry that resulted in a decrease in oil's role as a power generation fuel.

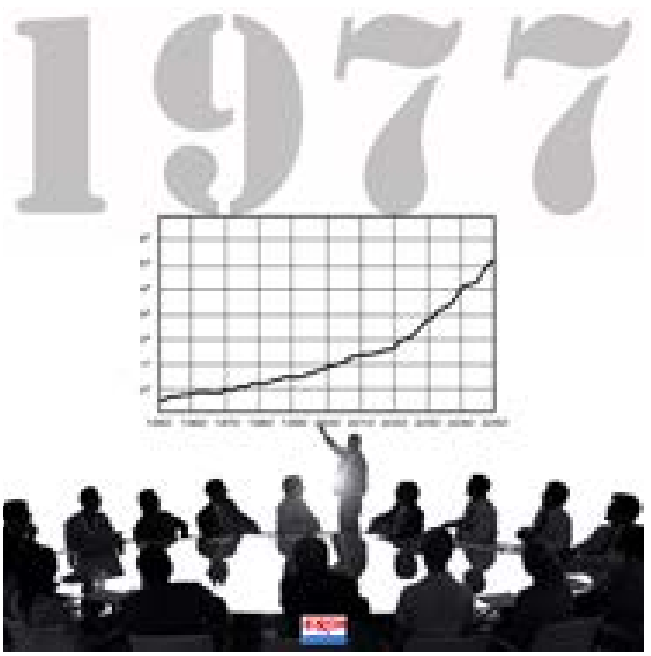

In 1977, senior scientists at major oil companies informed their executives that $\mathrm{CO}_{2}$ emissions from burning fossil fuels were potentially warming the planet at a catastrophic rate. Following a decade of further research there was general consensus in the scientific community that $\mathrm{CO}_{2}$ buildup in the atmosphere was a worldwide problem. A report by Exxon's engineering department stated that "fossil fuel consumption will cause dramatic environmental effects before the year 2050". The report even stated that there would be "major shifts in weather patterns" and "ocean levels would rise four feet" and "great irreversible harm to our planet". In 1988 NASA scientists testified about the issue before Congress, bringing it into the national consciousness, and lawmakers began calling for a reduction in $\mathrm{CO}_{2}$ emissions.

To derail these actions, oil companies spent fortunes casting doubt on the scientific evidence of the cause of climate change and confusing the public about greenhouse gases and $\mathrm{CO}_{2}$ emissions. The propaganda successfully promoted the notion that it was inconclusive as to whether human 


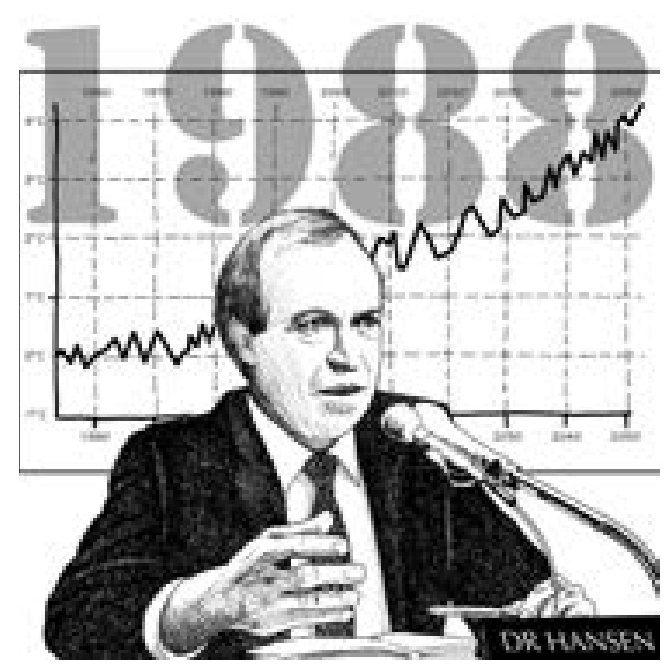

activities affect the global climate, and thus there was no reason to take drastic action. This shortsighted and devious strategy has been used successfully by other profitable corporations such as tobacco company campaigns to throw doubt on the cause-and-effect relationship between smoking and lung cancer. This nefarious gambit placed short-term profitability over human wellbeing.

Four decades later, oil can no longer be used as a weapon against the US, coal's negative impact on the environment is widely recognized, and as a fuel source coal is struggling to be competitive with lower-cost, less-polluting natural gas. What has not changed is that oil continues to be the dominant fuel that gets humans and goods from place to place. Until the transportation industry disentangles itself from oil-fired combustion engines, and embraces sustainable and renewable fuels, we will continue to be trapped in the $70 \mathrm{~s}$.

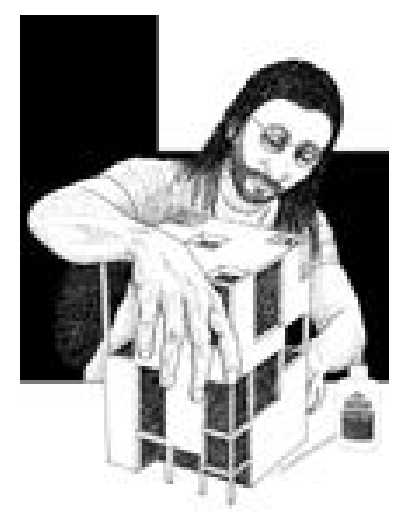

I was an architectural student from 1972 to 1978, and one-half of the academic buzz was enthralled by form-making and aesthetics. The other half was immersed in investigating architecture's role in solving the energy crisis. As I remember, we were taught that proficiency could be achieved by the building's orientation and plan proportion in relation to the site's latitude. In northern latitudes, elongation of the building form in the east-west axis yielded greater southern exposure for solar gain. Latitude also controlled the dimension of roof overhangs to protect from solar radiation and heat gain in summer months, while permitting the sun's radiation to passively heat the interior during winter months. Based on climatic zones, masonry buildings with high thermal mass and concrete floors were desirable as they could store the sun's energy during the day and dissipate the heat after sunset. And shading devices between floors could serve as reflective surfaces to bounce natural light to the innermost portion of the room if windows were strategically located above the overhangs. Insulated walls, windows, and roofs were a necessity; vapor barriers essential; and reduction of the building's surface areas exposed to the elements was a crucial factor in reducing heat loss and gain.
Dr. Hansen, NASA Director, testifies that the world is getting warmer in 1988 than any time in history
Architectural student exploring cubic form 
The formula drilled into budding architects was: Heat gain/loss (BTUs) = surface area (square feet) $\mathrm{x} U$-factor $(1 / \mathrm{R}) \mathrm{x}$ temperature differential (inside/outside).
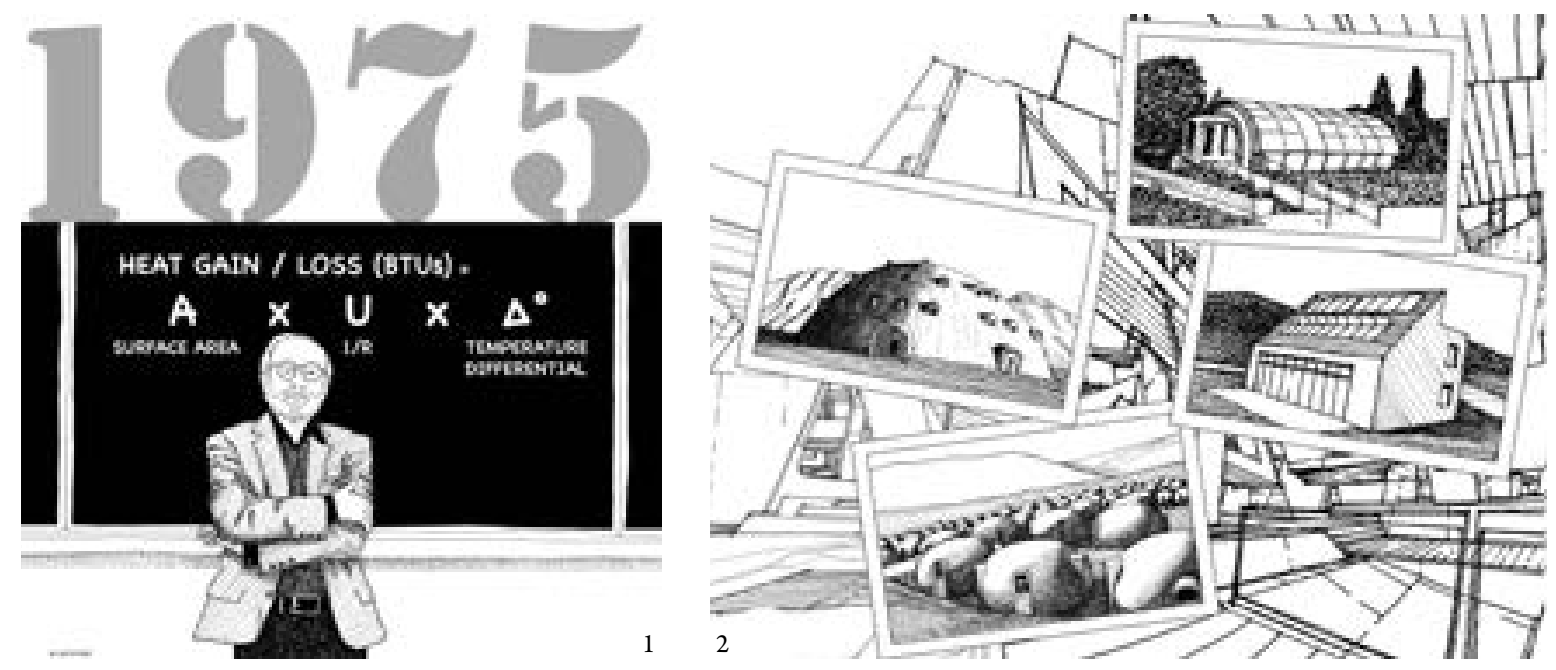

1: Mechanical Engineering class

2: Solar energy inspired forms
This basic formula considered the surface area, times the U-factor relating to insulation coefficient, times the temperature differential between inside and outside. The formula led to codes that substantially reduced glass areas within a wall surface, as glass has a lower R-value than an insulated wall surface. Focusing on the reduction of surface area led some architects to explore circular buildings and dome shaped structures as those forms enclosed maximum area and volume with the least amount of exterior surface area -think igloos. Architects interested in solar houses responded with shed roofs that were optimized for maximum solar gain and towers that lit the interiors with natural light. Form-driven architects relished the opportunity to explore new forms to increase energy efficiencies.

Surprisingly, there was little or no discussion regarding the efficiency of party-wall construction, exemplified by the row housing type that existed in most American cities. Urban buildings touch one another, hence there is no temperature differential on either side of the party walls, which makes them substantially more efficient than free-standing object buildings. Row housing permitted ownership of land -be it a small portion of land- by consuming less land per unit, creating viable neighborhoods with well-defined streets, and utility delivery was substantially more efficient than the suburban alternative. In hindsight, it was a missed opportunity for the revitalization of cities. However, the economic climate and perception of cities was not conducive to revitalization. In 1975, New York City was on the brink of bankruptcy, other cities were also on the decline, and the bias was clearly toward the suburbs with buildings that did not touch each other.

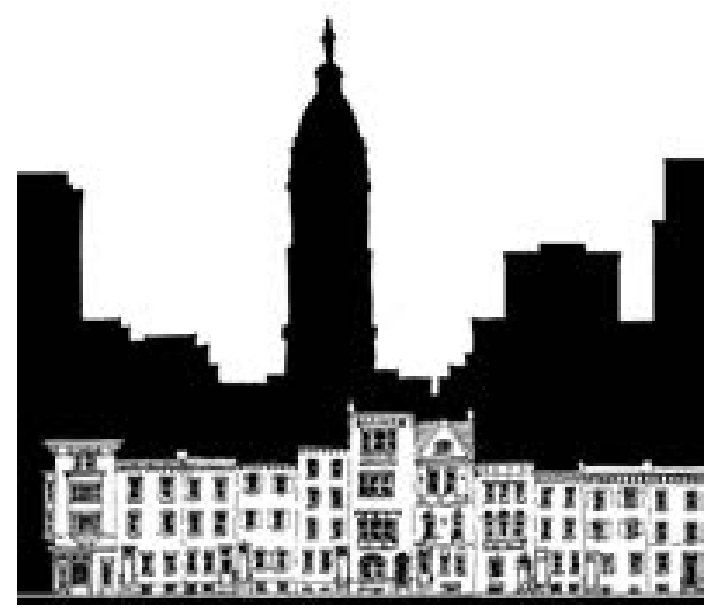


Historic building and wilderness preservation movements were established in the early $20^{\text {th }}$ century. In the US, public support flourished after the loss of New York City's Penn Station, leading to the National Historic Preservation Act of 1966. The Act reaffirmed the federal government's role in preserving the nation's historic sites. After the embargo of 1973, discourse on building preservation -regarding embodied energy in existing buildings, and energy consumed in making new building materials- encouraged many architectural schools to focus on preservation, restoration, and adaptive reuse. This spawned a cadre of architects skilled in materials and methodology of historic structures and an appreciation for preservation. The formmakers probably saw this as a setback, as preservation generally confined design to the parameters of the existing structure.

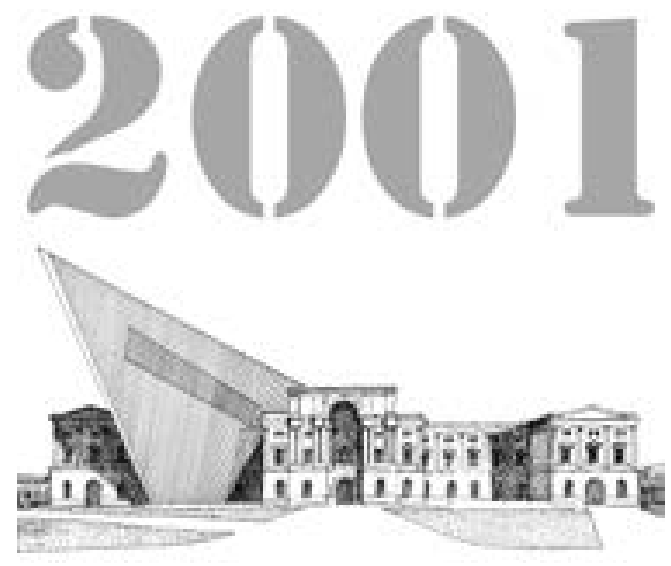

By the late 70s, professional organizations and corporations involved in the built environment were all promoting courses, seminars, products, and competitions that addressed adaptive reuse, energy efficiency, and passive-energy designed buildings. After a decade, the enthusiasm faded and the majority of academic institutions and professional architects and planners reverted to business as usual, and continued to explore new forms of expression.

Four decades later -with conclusive evidence and acceptance of climate change being caused by carbon dioxide emissions from the ever-increasing use of fossil fuels-academic institutions, professional architects and planners, and the marketing divisions of every industry have mobilized into bombarding the consuming public with a fresh set of buzzwords: Biodegradable, Carbon Neutral, Compostable, Eco-Friendly, Global-Warming Ready, Green, Low Carbon Footprint, Low VOC, Net Zero, Organic, Recycled, Renewable, Resilient, Smart Building, Smart City, Smart Growth, Sustainability. This technocratic focus has diverted attention from common sense architecture and urbanism that can actually deal with our global climate crisis.

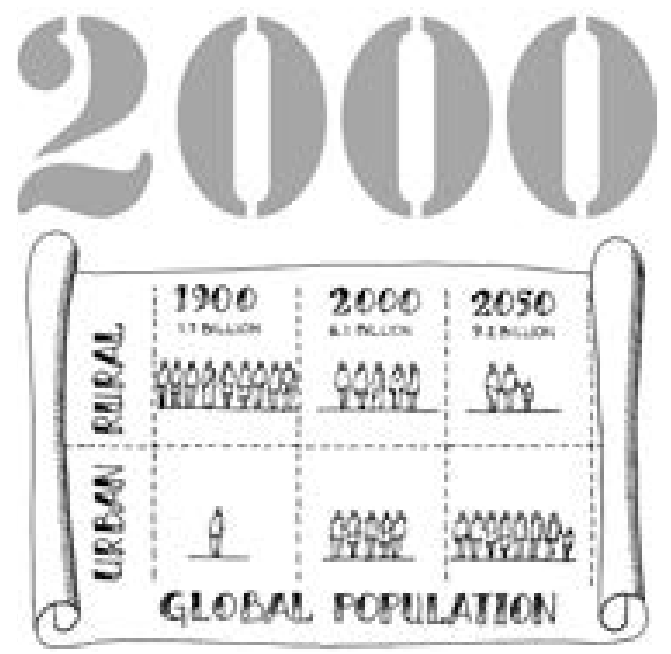

Libeskind attacks history

In 2000, global population was evenly divided between urban and rural 


\section{Revelation 3.0}

In the early years of the new century, a tsunami of crises coalesced -climate change, overleveraged mortgage loans, public health, burgeoning population, peak oil, and acute shortage of affordable homes.

The news flash in the year 2000, informed us that $50 \%$ of the world's population now lived in urban areas -a broadcast that has been grossly inflated and misunderstood, devaluing the meaning of urban life to a metric of density.

Urbanism is more than a statistic of the number of inhabitants in a finite area of land. Urbanism is a way of life complete with positive attributes that are based on a value system that strives for the collective good while respecting individuality. Foremost it is a way of life that embraces community and celebrates the exchange of ideas, goods, and services.

The hardware -the physical form of the city- is the physical manifestation and repository of its history, identity, and heritage, that responds to genius loci of place, climate, weather, humidity, precipitation, local soils and materials, and the natural environment. The software -the human social capital, traditions, and culture- embraces residents of varying incomes, diversity, race, and ethnicity. The democracy of the city respects and acknowledges the symbiotic relationships of the college-educated, vocationally-trained, self-taught, and apprentice-based workforce.

Without consideration for what true urbanism is, the conversation has drifted toward technological solutions to combat climate change, with little or no regard for the quality of life and wellness of the inhabitants. Software and computer hardware companies see an opportunity to sell their goods under the umbrella of "Smart City". Playing on the perception of cities being dangerous, fear propaganda has made surveillance cameras and monitoring facilities an easy sell. Sensors that monitor all aspects of infrastructure have also sold well, especially after an unforeseen disaster. Obviously, there is a place for technocratic solutions to monitor electrical power grids, test water quality, and measure emissions to assure healthy air quality, but these technocratic solutions should never dictate the urban design of our cities.

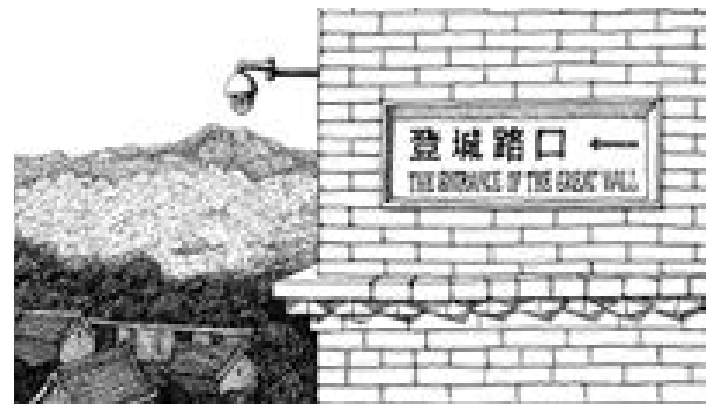

Images of proposed smart cities, all over the world, present brilliantly rendered views of new developments whose formal geometry and sculptural forms can only be appreciated in an aerial view when flying overhead in a helicopter. The architects of these large scale projects masterfully sell a futuristic lifestyle that proclaims to be efficient, smart, safe, and sustainable -by dazzling the public's imagination with forms that are only possible to imagine and build by using advanced modeling software programs driven by computer-jocks. This leaves the name-on-the-door architect to continually fund software programs which are necessary to make contorted building forms that have little regard for function, efficiency, or beauty.

In the 1950s politicians and decision makers were deceived into believing that expensive highway projects through cities would improve the quality of life and desirability of the cities. Sixty years later they are again being manipulated, this time by the catchy tag line of making their cities smart. Too often they welcome the carpetbaggers that travel the world to sell the city's emperors new sets of clothes. The emperors' advisors only have to remember the most basic formula -Heat 

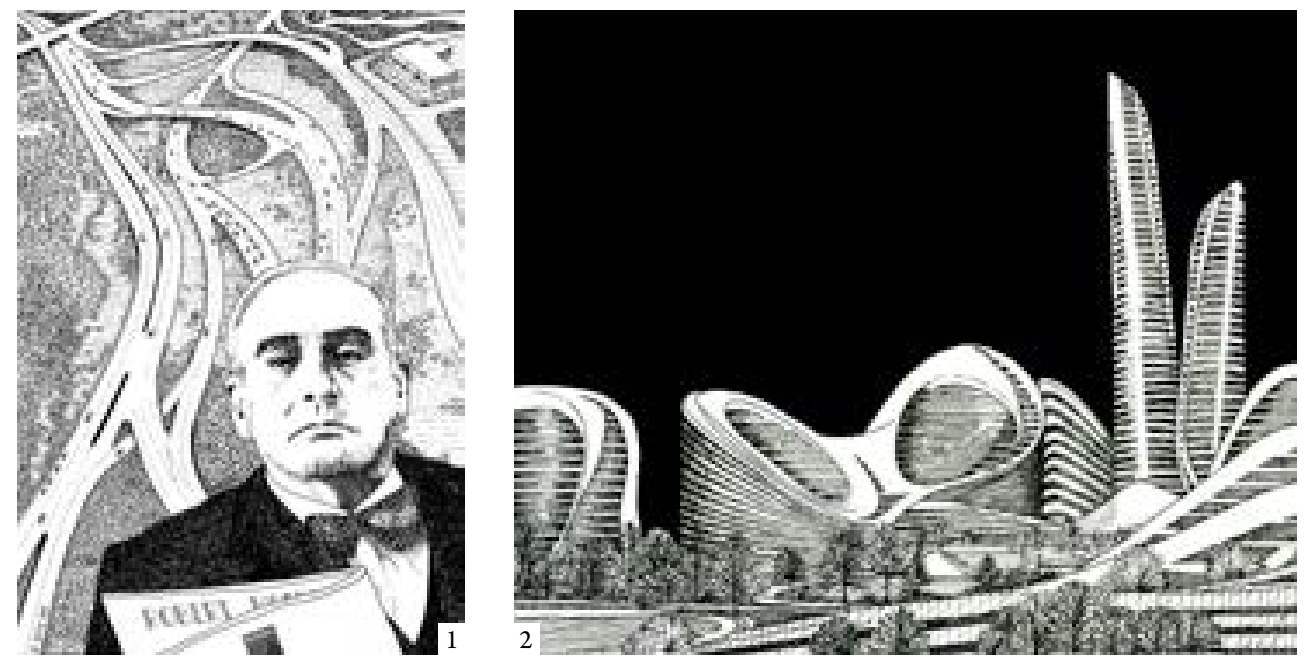

Gain/Loss = Area $\mathrm{x}$ U-factor $\mathrm{x}$ Temperature Difference - to realize that there is no "smart" in a city that is made of glass towers that maximize exposure of the building surface areas to the natural elements.

The unsustainable form of object buildings, and the intensive energy and resource consumption in making glass, only serve the architect's obsession with form and the hubris of insecure decision makers. Implicit in promoting these ludicrous unattainable propositions, the construction and realization of these faux smart cities will only lead to further distrust and apathy for all. The design profession must restrain its fixation with form and its dependence on technocratic solutions to solve problems that historically were resolved without intense energy consumption.

The unintended consequences of the abundance of cheap energy have steered designers to deemphasize solving problems of inclement climate, harsh weather conditions, and seasonal precipitation. Additionally, there is little thought given to limiting material selection to what is locally obtainable, selecting vegetation that is native, and employing construction methodology based on indigenous practices.

Traditional urbanism supported by Wi-Fi technology is the livable and sustainable alternative to what is being promised in breathtaking futuristic renderings of glass and steel structures within dumb "smart cities".

\section{WHAT IS A SMART CITY D}

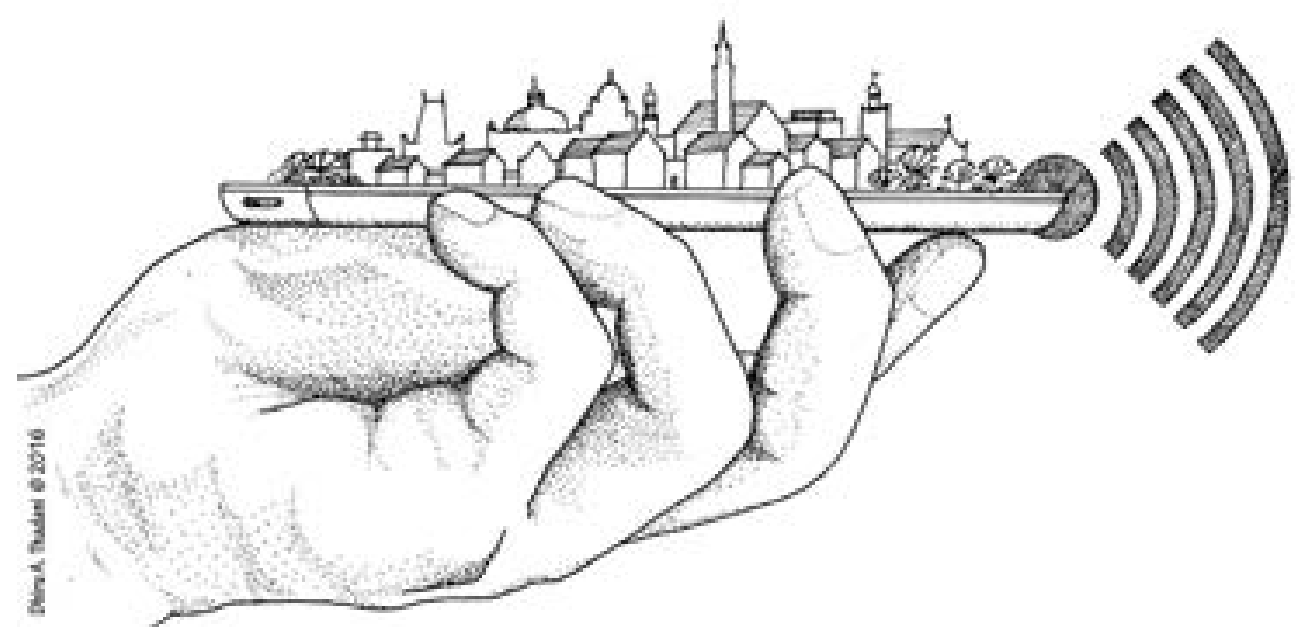

1: Similar to the promotion of the highway system by Big Oil, Big Asphalt, and Car Manufacturing Industries, "Smart" Cities are being promoted by corporations that have the most financial incentives

2: A proposed "Smart" City on the outskirts of Moscow 
Léon Krier explains that tradition is technology that works. This empirical knowledge is continually refined, adapted to changing human needs, and handed down through generations. The unambiguous goal is to improve the quality of life for the inhabitants through efficiency and consumption of the least amount of energy and resources. Materials are local, construction methodologies familiar, and forms respond to the cultural and physical contexts as well as to regional climate.

The global fascination for the shiny and new, and the unwarranted belief and reliance on captivating technology, drives high-profile architects to label anything traditional as nostalgic, unimaginative, and retrograde. Over the last century, the practice of separating uses for noxious reasons and eradicating the pedestrian realm in favor of vehicular movement have proved unsustainable. These practices that are preoccupied by machine-aesthetics and hostility toward the continuum of historical precedents may in fact be nostalgically holding on to a failed paradigm.

The last seventy years are but a small blip in the 5,000-year history of city-making. During this abnormal period, walking has been disregarded as the most sustainable form of travel. The promotion of private automobile conveyance has had catastrophic results, especially pollution, consumption of arable land by sprawl development, loss of life on a global scale of 3,700 autorelated fatalities a day, and financial impact on households having to purchase and maintain personal transportation as transit options were besmirched and demolished.

Instead of recognizing the failures of the recent past, the architecture profession doubles-down to resuscitate these unsustainable paradigms with green technology and wizardry under the "smart city" brand. The most efficient "green" building in the wrong location does not solve the overwhelming crises. Compact urban dwellings that are well connected internally and externally, and complete with walkable access to daily needs and a balance of jobs and beds, must be considered and implemented to follow traditional urban patterns.

Time-tested traditional urbanism consists of clearly demarcated public and private realms. These cities are an assemblage of autonomous neighborhoods with low-scale buildings that define blocks which are integrated into a memorable network of thoroughfares that connect a variety of public spaces.

Future neighborhoods and cities must be designed as if there is no or little external energy available, similar to the places that tourists continue to admire and visit. Places that are livable without excessive energy demands and where beauty prevails. Environments where the urban pattern encourages walking as the primary form of transportation to access human needs. Where civic life thrives and daily human interaction is serendipitous.

Such is successful urbanism.

\section{Biography $\mid$ Biografía | Biografia}

\section{Dhiru Thadani}

He is an architect, author, educator and urbanist who has been in practice since 1980. Dhiru was born in Bombay, in India, and moved to Washington, D.C. in 1972 to study architecture at the Catholic University of America. During his forty-eight years in Washington, D.C. he has taught, practiced, and strived to place architecture and traditional urbanism in the public eye. Since its formation in 1993, he has been a charter member of the Congress for the New Urbanism (CNU). He has been the principal designer of new towns and cities, urban regeneration, neighborhood revitalization, academic campuses, and infill densification projects, and authored a number of books and articles on urban design 